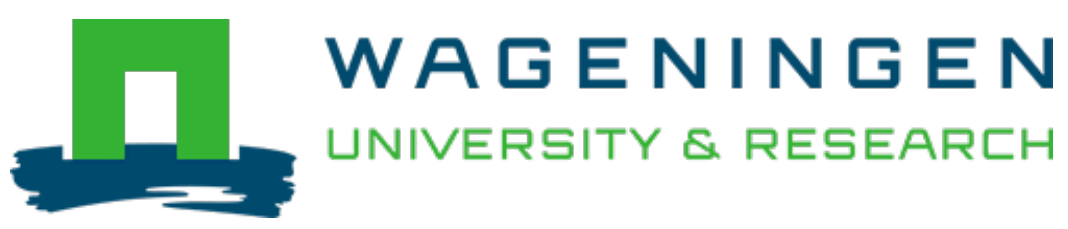

\title{
Critical success factors for the transition to business models for sustainability in the food and beverage industry in the Netherlands
}

\author{
Journal of Cleaner Production \\ Long, Thomas B.; Looijen, Arnold; Blok, Vincent \\ https://doi.org/10.1016/j.jclepro.2017.11.067
}

This article is made publicly available in the institutional repository of Wageningen University and Research, under the terms of article $25 \mathrm{fa}$ of the Dutch Copyright Act, also known as the Amendment Taverne. This has been done with explicit consent by the author.

Article 25 fa states that the author of a short scientific work funded either wholly or partially by Dutch public funds is entitled to make that work publicly available for no consideration following a reasonable period of time after the work was first published, provided that clear reference is made to the source of the first publication of the work.

This publication is distributed under The Association of Universities in the Netherlands (VSNU) 'Article $25 \mathrm{fa}$ implementation' project. In this project research outputs of researchers employed by Dutch Universities that comply with the legal requirements of Article $25 \mathrm{fa}$ of the Dutch Copyright Act are distributed online and free of cost or other barriers in institutional repositories. Research outputs are distributed six months after their first online publication in the original published version and with proper attribution to the source of the original publication.

You are permitted to download and use the publication for personal purposes. All rights remain with the author(s) and / or copyright owner(s) of this work. Any use of the publication or parts of it other than authorised under article $25 \mathrm{fa}$ of the Dutch Copyright act is prohibited. Wageningen University \& Research and the author(s) of this publication shall not be held responsible or liable for any damages resulting from your (re)use of this publication.

For questions regarding the public availability of this article please contact openscience.library@wur.nl 


\section{Critical success factors for the transition to business models for sustainability in the food and beverage industry in the Netherlands}

\section{A R T I C L E I N F O}

\section{Article history:}

Received 25 May 2016

Received in revised form

10 October 2017

Accepted 10 November 2017

Available online 13 November 2017

\section{Keywords:}

Organisational change management Business models for sustainability

Business model innovation

Sustainable business

\begin{abstract}
A B S T R A C T
Businesses will play a key role in helping the transition towards greater sustainability. To maximise business sustainability performance, sustainability characteristics must be integrated at the business model level, creating business models for sustainability. Creating a business model for sustainability, or transitioning from a traditional business model, is likely to be a complicated and challenging process. Previous research has identified a range of barriers, such as low financial reward or little legislative support.

The aim of this research is to explore and identify critical success factors and barriers for the transition from traditional business models to business models for sustainability. Previous research provides indications as to the barriers faced when attempting to develop business models for sustainability, but does so using conceptual lenses that emphasise external influences and factors. We seek to explore the process of business model innovation for sustainability from a perspective that pays greater attention to internal processes and from a management perspective, building on concepts of organisational change management.

The research focuses on start-ups and small and medium-sized enterprises (SME's) in the Dutch food and beverage industry. This is an interesting empirical context, as this is a dynamic, economically significant sector in the Netherlands, and is under pressure to improve its environmental performance. Data is collected from 14 cases, using semi-structured interviews, and is then analysed to identify a range of critical success factors and barriers. We find that collaboration, a clear narrative and vision, continual innovation, a sustainable foundation, profitability, and serendipitous external events are all critical success factors for the transition to business models for sustainability. Barriers include external events, principle-agent issues as well as a lack of support from wider actors and systems. The results highlight that businesses wishing to develop a business model for sustainability must make sustainability the key principle upon which the firm is founded. Continual development and improvement is required in addition to the support of a range of different actor's external to the firm, such as suppliers, customers, and government.
\end{abstract}

๑) 2017 Elsevier Ltd. All rights reserved.

\section{Introduction}

Business will play a key role in the move towards a more sustainable future. As the impacts of unsustainable practices increase, such as environmental destruction or exploitative working practices, there is a growing awareness for the need for sustainability (Raworth, 2005; Rockstrom et al., 2009). Change is needed at the individual, organisational and the systems level. At the

\footnotetext{
* Corresponding author.

E-mail address: tomblong9@aol.com (T.B. Long).
}

organisational level, it is businesses that exert significant influence over unsustainable production systems and consumption trends (Michaelis, 2003). Businesses are being driven to engage with sustainability issues due to greater scrutiny from society, the increasing value of reputation, and efficiency drivers. But, current business practices often remain unsustainable (Rockstrom et al., 2009).

For businesses to fully contribute to the transition towards sustainable development, sustainability principles need to be integrated into the core of business design, operation, and strategy (Stubbs and Cocklin, 2008). This is achieved through the creation of 
business models for sustainability (BMfS). Business models define how businesses create value, select customers, assign processes, and enter markets (Boons and Lüdeke-Freund, 2013; Chesbrough and Rosenbloom, 2002; Osterwalder and Pigneur, 2009; Osterwalder et al., 2005). The business model represents a foundational layer where sustainability can be fully integrated into a business, creating a BMfS (Osterwalder et al., 2005). A BMfS seeks profit across the 'triple bottom-line', generating sustainable value while reducing negative environmental and social impacts (Lüdeke-Freund et al., 2016; Schaltegger et al., 2016). A BMfS approach creates environmental and/or social value, in addition to the more usual economic outcomes (Bohnsack et al., 2014; Chun and Lee, 2013; Young and Tilley, 2006). Research has examined a range of critical questions, for example conceptualising and characterising BMfS (Bocken et al., 2014; Boons et al., 2013; LüdekeFreund et al., 2016), links to strategy and entrepreneurship (Bohnsack et al., 2014; Schaltegger et al., 2016), tools for their creation (Bocken et al., 2013; Geissdoerfer et al., 2016) and to business model innovation (Schaltegger et al., 2011).

The creation of BMfS requires innovation both in terms of the creation of new business models and adjustment to existing ones. Business model innovation differs from product or process innovation in that it involves changes to the foundational values of a firm, and is often radical and transformative with profound implications. The development of BMfS is subject to a range of barriers, including poor economic incentives, no legislative pressure or a lack of consumer acceptance (Asswad et al., 2016; Laukkanen and Patala, 2014). While these studies identify remedial actions, they do so within the contexts of open innovation (Asswad et al., 2016) or in terms of the wider innovation system (Laukkanen and Patala, 2014). These approaches focus on the external environment of the firm, potentially missing important internal factors. Adjacent literature has considered critical success factors, however, its application to the context of sustainable business model innovation is questionable. For instance, barriers and drivers to wider business model innovation have been explored (Chesbrough, 2010; Schneider and Spieth, 2013), however, this previous research assumes that business model innovation is driven by competitive advantage drivers, rather than sustainability aims. The pressures that drive business model innovation are likely to alter the factors that facilitate and inhibit the business model innovation process. Success factors have also been identified in terms of sustainable product innovation (de Medeiros et al., 2014), however, the business model innovation process is quite different in nature and impact (altering the foundations of a firm), again meaning the success factors may be different. A key question, therefore, concerns the factors that allow businesses to transition away from traditional business models and to develop and operate BMfS (Chesbrough, 2010; Schneider and Spieth, 2013; de Medeiros et al., 2014). This paper identifies the critical success factors for the transition towards BMfS. This is achieved by empirically exploring the success factors and barriers experienced by companies transitioning from traditional business models to BMfS, as well as companies that have been founded using a BMfS.

As a point of departure, we develop a framework based on organisational change management concepts to explore the factors and processes impacting the transition to (or creation of) BMfS. We show that whilst organisational change management concepts can serve as a useful conceptual base, the critical success factors that emerge from the empirical sample are quite different to those included within the literature. We find that collaboration, a foundation of sustainability, continuous innovation, a clear narrative and vision, a need for profitability and external events can all act as critical success factors. As such, we provide an initial assessment of critical success factors for the creation of BMfS. We focus our approach on the internal processes and factors associated with business model innovation with the use of management focused concepts, rather than from an innovation systems approach or in terms of open innovation, as with previous research (Asswad et al., 2016; Laukkanen and Patala, 2014). Our approach provides more focused perspective compared to research that explores the development of corporate sustainability (Lozano, 2013), but a more widely applicable contribution than that found for business models for sufficiency (Bocken and Short, 2016).

This research takes place within the Dutch food and beverage industry, which provides an interesting empirical context because the food and beverage industry as a whole is the largest industrial sector in the Netherlands, and the sector has a high environmental impact (Delahaye et al., 2013). Consequently, the creation of BMfS have the potential for both high economic, but also, environmental and social impacts. Since 2008, there has been a growing awareness of sustainability issues within this sector, driven by concerns for issues such as energy efficiency, climate change or animal welfare (FoodDrinkEurope, 2012; Reisch et al., 2013). As such, there are drivers for change and key issues that can act as catalysts around which business model innovations can take place. We focus on small and medium-sized companies or start-up firms, which are often the context within which radical innovations, such as those required for the creation of BMfS, emerge (Ebben and Johnson, 2005). This provides a dynamic context and the opportunity for an interesting research sample. The Netherlands was chosen as the geographical setting for issues of access and convenience, as all researchers were based in the Netherlands. Siting the study in one country meant all cases would be operating in a similar cultural and institutional context, limiting the number of variables impacting critical success factors and barriers.

\section{Literature review and conceptual framework}

Due to the nature of our question and to develop our theoretical framework, we review a range of different literature. First, to chart those factors previously highlighted as influencing how organisations change, we consider both mainstream organisational change management research as well as research more focused on the transition towards sustainability and BMfS. This provides an initial indication as to possible critical success factors. Second, we consider the stages that business go through in their journey towards sustainability, before, thirdly, examining the characteristics of BMfS. These three strands of literature are then synthesised into a theoretical framework which is utilised in the research design and explored using the data.

\subsection{Organisational change drivers and barriers}

The development of BMfS will require alterations to how a business operates, which will involve internal changes (Lozano, 2009b). Following this reasoning, concepts that address and explain how organisations change could aid in understanding how BMfS emerge, and the success factors and barriers involved. Organisational change management as a field of research identifies key factors that influence organisational change (Cameron and Green, 2009). We reviewed literature on organisational change management in general, and for sustainability in particular. Here, research ranges from more general considerations of how sustainability is integrated into corporate management and strategy (Lozano, 2013), how SMEs incorporate sustainability (van Hemel and Cramer, 2002), how these issues interact with the business case for sustainability (Schaltegger et al., 2011) and their role in the creation of business models for sufficiency (Bocken and Short, 2016). Key factors impacting change management are explored in 
turn below.

Leadership can be seen as a driver via proactive leadership, or as a barrier, in terms of non-active leadership or lack of leadership. Proactive leadership seeks to foresee and influence change as well as encourage a wide set of individuals to take part in decisionmaking processes, providing a compelling shared vision (Dawson, 1994; Lozano, 2009b; Roelofsen et al., 2015). The proactivity of the leader ultimately flows through the entire organization, providing a source of radical change, such as that associated with developing BMfS. A pro-active leader is also seen to encourage justice, diversity, resourcefulness and conservation (Hargreaves and Fink, 2012), which relate well to principles of sustainability. The corresponding change barrier is non-active leadership. For a transition to BMfS, this could mean that no top-down direction or drive is provided towards sustainability. Non-active leadership could take the form of a lack of active engagement with sustainability, acting at the level of individuals (Osagie et al., 2016; Wesselink et al., 2015), or a lack of strategy and managerial commitment, acting at the level of the organization (Lozano, 2013). A lack of leadership and communication has also been found inhibiting the creation of business models for sufficiency (Bocken and Short, 2016).

Economic benefits form the second key factor. Available economic benefits represent a driver, whilst a failure to identify potential economic benefits diminishes or eliminates this driver for change (Cannon, 1994; Benn et al., 2014; Lantos, 2001; Schaltegger et al., 2011). Indeed, The Natural Step (2016) highlights the importance of a return on investment for any sustainability initiative to be successful. This makes it likely that such a factor would play a key role in the successful development of or change to a BMfS. Other research highlights that sustainability benefits, or the lack of them, are also an important driving factor (van Hemel and Cramer, 2002).

Aspiration is a factor for change, as in management terms, aspiration relates to an individual's (i.e., the employees) desire for achieving realistic goals and experiencing a sense of accomplishment (Senge, 2000). Levels of aspiration impact an organization's capacity to learn and change. Aspiration produces continuous learning and growth. Aspiration can also be linked to the extent to which sustainability is integrated into the ambitions and mission statement of an organization, and is noted in terms of change towards corporate sustainability specifically (Benn et al., 2014; Senge, 2000). The corresponding factor that can inhibit change is apathy, or to an extreme, fear (Cameron and Green, 2009). This could be linked to perceived threats to job security or to a lack of trust (Lozano, 2013). Apathy results in little drive or care for change, and whilst fear can produce short-term results, these are likely to be associated with a negative vision, limiting long-term impacts (Senge, 2000).

External factors can be a crucial influence in the decisionmaking process for implementing change in an organization. This is a broad factor, encompassing a range of specific drivers or barriers, external impacts such as political and financial upheaval, new technologies, regulatory change, worldwide competition, and consumer preferences can have an influence on the need for change (Dawson, 1994; Ditlev-Simonsen and Midttun, 2011; van Hemel and Cramer, 2002). External factors can influence if and how sustainability is implemented in an organization; for example, a lack of governmental support may decrease the willingness to implement sustainability in an organization, whereas a clear market demand for products or services with a low environmental impact would enhance the transition towards a sustainable business model.

To see and respond to changing market demands or to act in response to problems such as climate impacts, firms need the ability to identify the nature and cause of events. 'Diagnosis' or awareness are subsequently key factors for successful organisational change (Cameron and Green, 2009; Carr, 2001; The Natural Step, 2016). For example, a business has to be able to recognise an opportunity to decrease costs and enhance the customer offering through a product-service-system, for the business model to change. Diagnosis can be a change barrier either where awareness is lacking, or where the outcome of the assessment or diagnosis is incorrect.

The final factor is the existence of visible crises, where an upsurge in negative events attracts the attention of managers (Kotter, 1996). Market failures or eco-system failures like global warming drive the change towards sustainability and convince the entrepreneur to transition to a sustainable business model. For example, high-profile accidents in Bangladeshi garment factories, including the 2012 Dhaka fire and 2013 Savar building collapse, led to action by clothing brands and retailers supplied by the region. These retailers sought alternative suppliers or introduced new efforts to ensure minimum safety standards (Henniker-Major, 2014). If there is no indication of a crisis, however, then there is no urgency to implement change. Therefore, the downturn of visible crises has a negative effect on change (Kotter, 1996).

The above noted factors emerged from our review of literature which focused on organisational change management, both more generally and change management for sustainability, and are illustrated in Table 1 . They highlight that a range of internal and external factors can both drive and inhibit change and transformation processes. The extent to which these factors are applicable in the context of transformations needed to create BMfS will be explored through the data. Additional conceptual perspectives will also be explored, including the transition to sustainable business and the general factors involved in business model innovation.

\subsection{The transition towards sustainable business}

The business transition from a profit maximising orientation towards a more holistic or sustainable view of goals and performance is not a new area of study (Benn et al., 2014; Keijzers, 2002; Visser, 2014). A common narrative exists, noting an initial rise in environmental regulation in the 1970 s, followed by increasing engagement with eco-efficiency and resource conservation with the release of the Brundtland report from the late 1980s. New forms of governance, such as voluntary agreements and other activities associated with corporate sustainability, emerged alongside these

Table 1

Key factors impacting organisational change as identified and synthesised from the literature.

\begin{tabular}{|c|c|}
\hline Factor Impacting Organisational Change & Source \\
\hline Leadership & Dawson (1994); Hargreaves and Fink (2012); Lozano et al. (2015); Blok et al. (2015) \\
\hline Economic benefits & Benn et al. (2014); Cannon (1994); Lantos (2001); Schaltegger et al. (2011); The Natural Step (2016) \\
\hline Fear or aspiration & Cameron and Green (2009); Senge (1999) \\
\hline External influences & Dawson (1994); Ditlev-Simonsen and Midttun (2011); van Hemel and Cramer (2002) \\
\hline Awareness and ability to diagnose & Cameron and Green (2009); Carr (2001) \\
\hline Existence of visible crises & Henniker-Major (2014); Kotter (1996) \\
\hline
\end{tabular}


Table 2

Business Ages and Stages of corporate sustainability, adapted from Visser (2014).

\begin{tabular}{lll}
\hline Business Age & Stage of Corporate Sustainability & Modus Operandi \\
\hline Greed & Defensive & Ad hoc \\
Philanthropy & Charitable & Community programmes \\
Marketing & Promotional & Public relations \\
Management & Strategic & Management systems \\
Responsibility & Transformative & Business models \\
\hline
\end{tabular}

shifts (Keijzers, 2002).

These shifts can be categorised into phases. Visser (2014) describes five overlapping stages which, similarly to Keijzers (2002), account for the observable trend, as well as providing some normative vision for what sustainable business will look like in the future (see Table 2). The final phase or stage of transition, that of Transformative corporate responsibility, is where the root causes of unsustainable and irresponsible practices are tackled through business model innovations. At the transformative stage of corporate sustainability, the principles of creativity, scalability, responsiveness, glocality (global-local balance) and circularity (closedloop production principles) are seen to act as a foundation to sustainable business (Visser, 2014).

Van Tilburg et al. (2012) contribute here with their work on sustainable entrepreneurship, which introduced four phases characterising the stance of a business towards sustainability. These phases are inactive, reactive, active, and proactive (highlighted in Table 3).

The inactive phase is characterised by seeing sustainability as a task for the government, and where there are few advantages for entrepreneurship to focus on sustainability. Organisations in the reactive phase are more socially responsive compared to the inactive phase, but focus mainly on reputation and so cannot be considered to have drastically altered business models.

In the active phase, businesses see sustainability as a market opportunity and as a driver for innovation. Whereas the inactive and the reactive phase are associated with traditional business models, businesses in the active phase can be seen to start to develop some characteristics of BMfS. Businesses in the active phase start to improve their products or services by sustainable innovation.

In the proactive phase, the strategy of the company is inherently intertwined with sustainability challenges (Stoughton and Ludema, 2012; Van Tilburg et al., 2012). Both Van Tilburg et al. (2012) and Visser (2014) highlight a move from traditional, enclosed and profit driven modes of business, towards more holistic strategies, where sustainability is incorporated into the core of the business model. The core difference between the authors can be seen in the number of phases each identifies (i.e. four versus five). However, one can argue that the inactive phase of (Van Tilburg et al., 2012) includes both the defensive and charitable phases of Visser (2014). We synthesise the contributions of Visser (2014) and Van Tulder et al. (2013) (see Table 4), as this provides a clear outline of various stages in a business's transition towards a more sustainable orientation.

Schaltegger et al. (2011) highlight the different degrees and innovation stages involved in the creation of BMfS. These include:

- Adjustments, where only a small change is made, which does not include the value proposition.

- Business model adoption, where a business model is changed to match or mirror a competitors' changes.

- Business model improvements, where most elements of the business model are changed and improved.

- Business model redesign, where improvements mean that a new value proposition is developed.

These stages relate well to the work of both Van Tilburg et al. (2012) and Visser (2014), and similarly chart the various degrees or types of sustainability engagement, but at the business model level. However, this focus on the business model means that wider factors, such as the role and impact of corporate culture, reporting and transparency are omitted.

This changing stance of business fits within a wider literature concerned with socio-technical transitions towards sustainability. Changes at this systems level - in terms of technology, politics, the economy and culturally - will occur simultaneously with changes in the way that businesses operate (Loorbach et al., 2009). Business models provide a conceptual link between the changes in businesses that are required and the changes to systems (Boons et al., 2013). This transition thinking also provides businesses with strategies. For example, Loorbach et al. (2009) notes first that the coevolution with systems change means that firms may need to experiment first, before moving fully towards new business models. And second, that if firms first identify and address sustainability issues at the societal level, they can then create business models that specially address these issues.

Factors that inhibit the development and diffusion of BMfS have been identified (Laukkanen and Patala, 2014). Different barriers are identified for the different orientations that BMfS innovation takes, including technological, social, and organisational barriers. For instance, a lack of legislative pressure and too few economic

Table 3

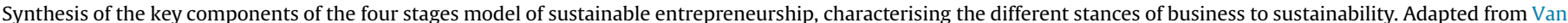
Tilburg et al. (2012).

\begin{tabular}{|c|c|c|c|c|}
\hline & \multicolumn{4}{|l|}{ Conduct } \\
\hline & Inactive & Reactive & Active & Pro-Active \\
\hline Vision on Sustainability & None & General statements & Focus on societal contribution & Holistic, strategic \\
\hline $\begin{array}{l}\text { Orientation external } \\
\text { developments }\end{array}$ & None & $\begin{array}{l}\text { External adduced, business, } \\
\text { location }\end{array}$ & Market and products or services & Cosmopolitan, society \\
\hline Business case Elements & Costs, clients, and law & $\begin{array}{l}\text { Costs, clients, law, and } \\
\text { reputation }\end{array}$ & $\begin{array}{l}\text { Costs, clients, law, reputation, and } \\
\text { identity }\end{array}$ & $\begin{array}{l}\text { Costs, clients, law, reputation, } \\
\text { identity, long-term continuity }\end{array}$ \\
\hline Transparency & None & On request & Product and chain & Full transparency \\
\hline Reporting & $\begin{array}{l}\text { None, or legally obliged } \\
\text { environmental reporting }\end{array}$ & $\begin{array}{l}\text { Separate sustainability report } \\
\text { focused on process }\end{array}$ & $\begin{array}{l}\text { Sustainability reporting with focus on } \\
\text { core themes and products }\end{array}$ & $\begin{array}{l}\text { Integrated with intertwined } \\
\text { strategy }\end{array}$ \\
\hline Stakeholders & $\begin{array}{l}\text { Government, important } \\
\text { clients }\end{array}$ & $\begin{array}{l}\text { Government, clients, } \\
\text { suppliers, some NGO's }\end{array}$ & $\begin{array}{l}\text { Government, clients, suppliers, NGO's, } \\
\text { employees }\end{array}$ & Society \\
\hline Supply Chain approach & No sustainable aspects & $\begin{array}{l}\text { Minor conduct codes for } \\
\text { suppliers }\end{array}$ & $\begin{array}{l}\text { Engagement and broad codes of } \\
\text { conduct }\end{array}$ & Co-creation \\
\hline $\begin{array}{l}\text { Dominant Functional } \\
\text { Discipline }\end{array}$ & Operations, legal & Public affairs & Corporate communication and HR & Management/Board and strategy \\
\hline
\end{tabular}


Table 4

Synthesis of phases to sustainable business approaches of Visser (2014) and Van Tilburg et al. (2012).

\begin{tabular}{|c|c|c|}
\hline Visser & $\begin{array}{l}\text { Van Tilburg } \\
\text { et al. }\end{array}$ & Characteristics \\
\hline Defensive & Inactive & Ad hoc, no to limited vision of sustainability, little engagement externally. \\
\hline $\begin{array}{l}\text { Charitable } \\
\text { Promotional }\end{array}$ & Reactive & Limited external orientation, some community programmes, and public relations. Some reporting. \\
\hline Strategic & Active & $\begin{array}{l}\text { Increasing focus on products and supply chain sustainability using management systems, with sustainability reporting focused on } \\
\text { products and internal strategies. }\end{array}$ \\
\hline Transformative & Proactive & Holistic approach to sustainability fully integrated into business models and business strategy. \\
\hline
\end{tabular}

incentives inhibit technologically orientated BMfS, while consumer related factors, as well as attitudes and values inhibit the diffusion of organisational oriented BMfS. These factors were highlighted through an innovation systems approach, exploring how the different functions of an innovation system interacted with the diffusion of BMfS.

The frameworks and literature reviewed above provide a basis from which to understand the transition from traditional to BMfS. They also provide criteria that aid in highlighting suitable empirical examples for this research. In the next section, we will identify more explicit BMfS characteristics.

\subsection{Characteristics of business models for sustainability}

BMfS aim to provide products or services that directly or indirectly reduce the pressure on society and the environment while still generating profits equal to or greater than traditional business (Bocken and Short, 2016; Bohnsack et al., 2014; Chun and Lee, 2013).

Initial engagement with the topic of BMfS focused on the added value to corporate sustainability that could be achieved by examining and altering the foundations of organisations (Stubbs and Cocklin, 2008). This led to the notion that the creation of BMfS requires radical shifts in the way that businesses operate, as incremental changes are likely to be able to be incorporated into existing traditional business models (Schaltegger et al., 2011). This mirrors the distinction between 'bolt on' sustainability actions (associated with corporate social responsibility) versus more fundamental shifts that are required in order to achieve 'sustainable business' (Long et al., 2015). These early approaches sought to impact external stakeholders and the wider socio-economic environment, for example by encouraging reform of energy and transport systems, or the re-designing of accounting systems to place less emphasis on short-term financial goals (Stubbs and Cocklin, 2008).
Later contributions started to articulate the specific characteristics and forms of BMfS. For example, that the value proposition should include ecological, social and economic values (Boons and Lüdeke-Freund, 2013); that supply chain management should include a focus on sustainability; that customer services maintain prolonged relationships with customers; and that firms take responsibility for their production and consumption systems (i.e. consumer education models, product assistance, and transparency) (Blok et al., 2015; Boons and Lüdeke-Freund, 2013; Tencati and Zsolnai, 2012). Costs and benefits should be more equally distributed with, for example, suppliers (i.e. ethical trade), and there should be a broader, more democratic, and balanced governance system (Boons and Lüdeke-Freund, 2013; Tencati and Zsolnai, 2012). Alternatively, that the business model should aim for sufficiency, involving the reduction of customer demand reducing material inputs (Bocken and Short, 2016). An examination of how best to optimise business models for sustainable technology diffusion found that the business model had to be addressed as a whole, rather than making changes to different aspects of the business model in isolation (Long et al., 2017).

Efforts have also been made to provide more practical categorisations of sustainable business models, with the aim of seeking ways to transform negative outcomes into positives, to tackle the demands of stakeholders and seek new unique ways of sustainable value creation. These include a deductive approach via a review of 87 business models seen as providing sustainability benefits, which identified five categories of BMfS (Clinton and Whisnant, 2014). These included those that reduce environmental impact, via closed-loop production or 'physical to virtual' production for example; or those that impact social elements, via 'buy one, give one' schemes or cooperatives; base-of-the-pyramid (BoP) approaches; as well as financing innovations, such as crowdsourcing or service orientated sales models, replacing customer ownership of products.

A comprehensive contribution is provided by Bocken et al.

Table 5

Business models for sustainability archetypes (Bocken et al., 2014).

\begin{tabular}{|c|c|c|}
\hline & Construct & Approach and Examples \\
\hline \multirow[t]{3}{*}{ Technological } & $\begin{array}{l}\text { Maximisation of material and } \\
\text { energy efficiency }\end{array}$ & $\begin{array}{l}\text { Doing more with less, minimising waste, emissions, and energy use. Examples include re-manufacturing or } \\
\text { dematerialization, low-carbon manufacturing; lean manufacturing). }\end{array}$ \\
\hline & Creating value from waste & $\begin{array}{l}\text { Valorisation of by-products such as emissions through re-processing or product take-back schemes. Other examples } \\
\text { include cradle-to-cradle thinking, closed-loop supply chains, circular economy. }\end{array}$ \\
\hline & $\begin{array}{l}\text { Renewable and natural process } \\
\text { substitution }\end{array}$ & $\begin{array}{l}\text { Increasing the use of renewable energies, biomimicry, or green chemistry. Examples include renewable energy sources, } \\
\text { biomimicry, or green chemistry. }\end{array}$ \\
\hline \multirow[t]{3}{*}{ Social } & $\begin{array}{l}\text { Delivering functionality over } \\
\text { ownership }\end{array}$ & $\begin{array}{l}\text { Business provides services that satisfy the stakeholders' needs without having to own physical products, such as pay- } \\
\text { per-user and product system approaches. }\end{array}$ \\
\hline & $\begin{array}{l}\text { Adopting a stewardship } \\
\text { approach }\end{array}$ & $\begin{array}{l}\text { Undertaking proactive engagement with stakeholders via a long-term outlook. Examples include biodiversity } \\
\text { protection, ethical trade, or choice editing by retailers. }\end{array}$ \\
\hline & Encouraging sufficiency & $\begin{array}{l}\text { Utilising and implementing solutions which actively seek to reduce production and consumption, moving away from } \\
\text { having to maximise material sales to maximise profits. For example, consumer education; demand management; } \\
\text { product longevity. }\end{array}$ \\
\hline Organisational & $\begin{array}{l}\text { Repurpose for society and/or the } \\
\text { environment }\end{array}$ & $\begin{array}{l}\text { Business is focused on delivering social and environmental benefits, instead of singular focus on economic profit } \\
\text { maximisation. For example, using not-for-profit; hybrid businesses; localization; or base of pyramid solutions. }\end{array}$ \\
\hline & Develop scale-up solutions & $\begin{array}{l}\text { Business aims to deliver sustainable solutions at a larger scale to maximise the benefits for the society and the } \\
\text { environment rather than the company itself. For example, Incubators; open innovation; or crowdsourcing/funding. }\end{array}$ \\
\hline
\end{tabular}


(2014), who identifies eight archetypes by assessing available examples for business model innovations for sustainability. These are split into technological, social, or organisational categories. Each are summarised in Table 5.

The archetypes approach holds value as it identifies methods for enhancing sustainability, before grouping these methods according to their impacts and approach.

\subsection{Conceptual framework}

To identify critical success factors for the transition towards BMfS, we propose a framework based on the organisational change management literature reviewed in section 2.1. We conceive of the transition to BMfS as occurring in the active/strategic phase as described by Visser (2014) and Van Tulder et al. (2013), with a BMfS having been achieved in the proactive/transformative phase. We argue that a BMfS is not possible in these earlier phases. For instance, in the strategic/active phase, where there is increasing focus on products and supply chain sustainability using management systems, with sustainability reporting focused on products and internal strategies, a BMfS has not yet been implemented. Design and initial preparatory steps could be occurring in this phase. The transformative/proactive phase is where BMfS are implemented, as this phase is characterised by a holistic approach to sustainability fully integrated into business strategy and organisational design.

While we depict the transition to sustainability as a phased process, with firms advancing from each phase in sequence, it is likely to be possible for firms to skip phases. For instance, it may be possible for a firm to jump from inactive/defensive to active/strategic phase. For graphical simplicity, we do not illustrate this possibility within Fig. 1. The conception provided illistrates the timeline and process backing needed for our understanding. To answer the research questions, however, we must identify the factors that enable and drive this transition.

To guide our identification of critical success factors, we take an organisational change management approach, as outlined in section 2.1. This literature explores those factors that allow organisations to make changes (Cameron and Green, 2009; Lozano, 2009a), in this case the change to a BMfS or the creation of a BMfS. BMfS will require alterations to how a business operates involving internal changes (Lozano, 2009a). Using organisational change management concepts allows an emphasis of these internal processes, while also leaving room to acknowledge the impact of external and environmental forces.

While this study focuses on identifying critical success factor, it is likely that some factors will also act as barriers to the development of BMfS (Laukkanen and Patala, 2014). As such, we also include barriers highlighted within previous examinations of organisational change management. Fig. 1 illustrates the conceptual backing to the research based on the review of the literature and includes the transition to BMfS as well as key organisational change factors.

\section{Methods: data collection and data analysis}

To answer our research question we required empirical data and evidence. To achieve this, we firstly needed to identify examples of business models that could be characterised as BMfS. This then allowed data to be gathered on how the BMfS were created. We based identification on the definitions and typologies developed by previous scholars.

To identify BMfS within the food and beverage industry, two complementary concepts of sustainable business are used. Using two concepts was felt to increase the robustness of the method for

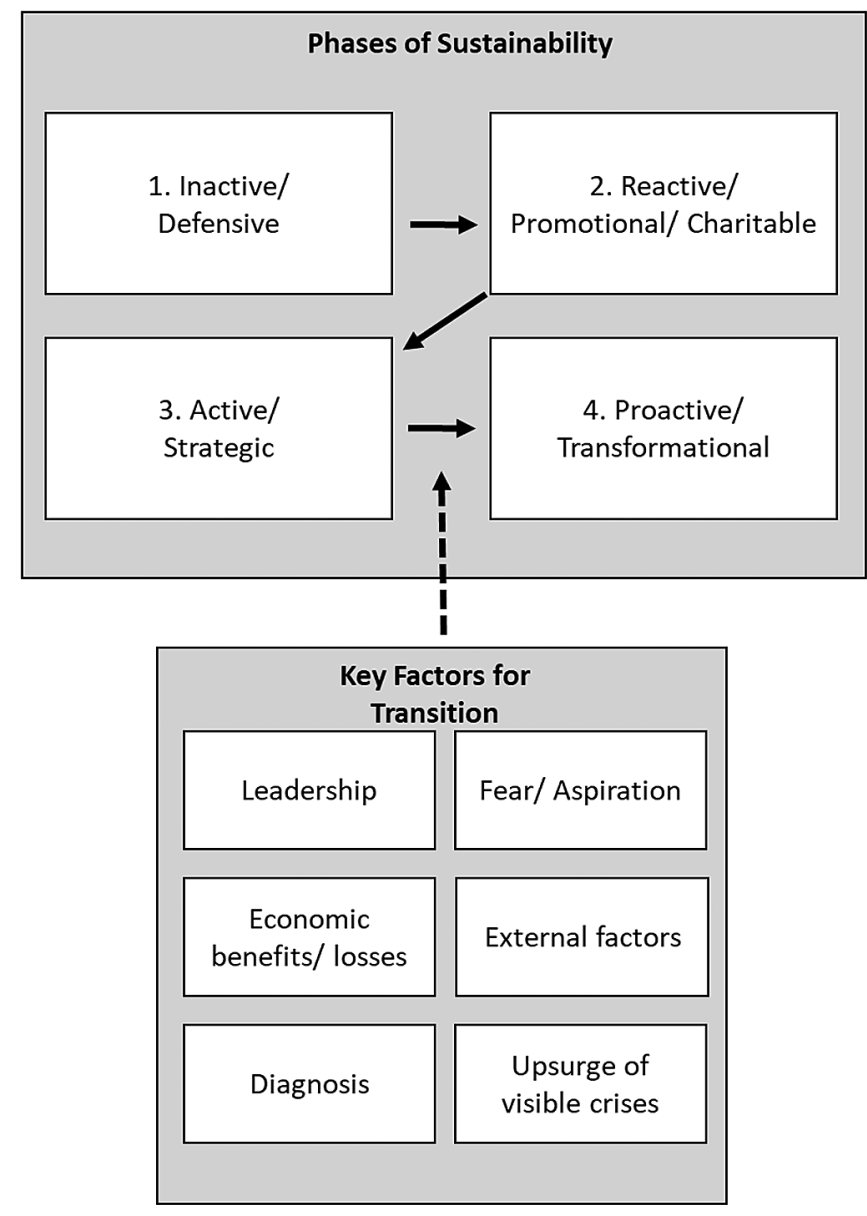

Fig. 1. Development of BMfS success factors and barriers overview framework.

identifying suitable examples. The first concept we draw upon are the transition towards sustainable business (see section 2.2), where we synthesise the contributions of Visser (2014) and Van Tulder et al. (2013) (see Table 4). The second concept acts in a more confirmatory way and seeks to characterise the specific forms of the BMfS, using the characteristics developed by Bocken et al. (2014) (i.e. creating value from waste, encouraging sufficiency etc.). This approach is taken partly due to difficulties in applying the archetypes categories (Bocken et al., 2014) to practical or empirical examples.

The transformative/proactive phase is most relevant for this research because sustainability aspects have been integrated into the business model (Van Tilburg et al., 2012; Visser, 2014); using these concepts, we derive selection criteria for the identification of cases as shown in the last two columns of Table 3. For example, criteria include a holistic and strategic vision on sustainability, a societal orientation or a co-creating approach to supply chain relations. Only businesses with activities consistent with these requirements are included in the research sample.

With this twinned approach (i.e. sustainable business model archetypes and the phase of sustainable business), we construct a classification system based on two sets of criteria. This is analogues to previous research that has sought to identify BMfS; for example, Birkin et al. (2009), in their study of BMfS in China, identified potential empirical examples by searching for companies that displayed a recognition of the importance of sustainable performance through innovations for sustainable development, certification (i.e. ISO140001) or local awards. 
Further, whilst the archetypes are not necessarily 'phase dependent', it is conceivable that they could be found within the active phase. For instance, whilst archetypes such as encouraging sufficiency or repurposing for society and/or the environment are likely only to be possible in the proactive or transformation phase, creating value from waste or maximising material and energy efficiency could conceivable to be achieved during the strategic or active phase. This provides a further rationale for including the transition to sustainable business elements into the case identification approach.

\subsection{Data collection}

Although existing research and theory from adjacent topics was utilised to develop a theoretical framework, the research question examines an area of knowledge were little is understood. Further, our questions are of a 'how' and 'why' nature, requiring rich and indepth data. This indicates that a qualitative and analytic inductive approach is most appropriate (Gilgun, 2011, 2015; Saunders et al., 2009). By using analytic induction, we utilise and integrate existing theory and research. Whilst using existing theory, we remain open to new interpretations and are sensitive to our specific empirical contexts (O'Reilly et al., 2012). This allows us to develop further theoretical propositions and insights.

Following this stance, data was acquired from businesses who had BMfS in order to understand those factors that could be considered to have aided or hindered the transition.

The first step to identify and recruit cases involved scanning the food and beverage sector in the Netherlands, via internet searches and discussions with industry. An initial list of more than 60 cases was developed; during this process, start-ups and SMEs were included if evidence of sustainability initiatives being incorporated into their business models could be found, which is analogous to the approach undertaken by Birkin et al. (2009).

Next, further investigation of the short-listed companies was undertaken to assess where in the phases of sustainability strategy model they were; only those businesses that could be considered to be in the proactive/transformational phase were included (see criteria set out within Table 5). Businesses that were assessed as being within the pro-active phase were then approached for formal interviews. Using the interview data, they were then assessed again to confirm that they were in the proactive/transformational phase and that they incorporated at least one of the BMfS archetypes (see section: Characteristics of Business Models for Sustainability). These were determined to be the minimum requirements for inclusion within the research, and to ensure that we had relevant, interesting, and appropriate cases. An overview of this process is outlined in Fig. 2.

Data were collected from a total of 15 businesses. One business was excluded from the sample as it was a subsidiary of a larger multinational company and as such not readily compatible with the SME's $(n=6)$ and start-ups $(n=8)$ that formed the rest of the sample.

The interviews followed a semi-structured format, consistent with the need for rich and in-depth data. Questions for each set of concepts as described in section 3 were included. The authors based the questions on the variables and constructs of the different models as can be found in Appendix.

The interviews lasted between the 45 min and $1 \mathrm{~h} 45 \mathrm{~min}$. Interviews were conducted either face-to-face or via telephone. All the interviews were recorded and transcribed in Dutch, and then translated into English. An overview of the businesses included in the research can be found in Table 6. Table 6 notes the size of the company and the focus of the business, its sustainable orientation and achievements, as well as the sustainability phase the businesses was assessed to be in, as described by Van Tilburg et al.

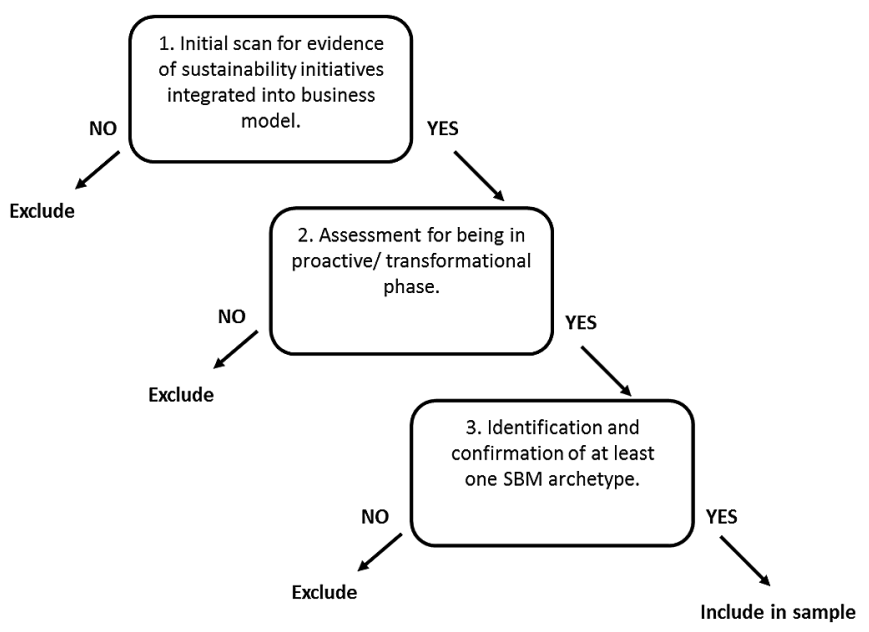

Fig. 2. Process for assessment and inclusion of businesses within the research.

(2012) in Table 3. Where the 'Pro-active ex. reporting' is noted in the last column, this is referencing that many of the firms fit all of the pro-active sustainability phase criteria apart from the requirement of integrated reporting. It was felt this was due to many of the firms being SMEs, where reporting is uncommon, rather than a reflection of their sustainability orientation.

\subsection{Data analysis}

After transcribing and translating the interviews, coding was undertaken. This was a two-step process. Analysis first focused on case selection and qualification, where coding was based on the criteria and categories developed through the literature review and conceptual framework. Second, open coding identified critical success factors and barriers for the development of and transition to BMfS.

In step one, to qualify the cases of BMfS, coding was based on BMfS archetypes and the transformative/proactive sustainability phase criteria. In this initial phase, the authors scored the companies from 0 to 8 for both models illustrating the number of types of conduct or archetypes they exhibited.

Eleven of the 14 cases scored 7 out of 8 on the constructs associated with the proactive/transformational phase of the transition to sustainable business (see Table 5), with the other businesses scoring 8 out of 8 . All cases scored at least 4 out of 8 archetypes of BMfS (see section: Characteristics of Business Models for Sustainability). For instance, case one, a start-up based on sustainable home food delivery exhibited all proactive/transformational characteristics, except the reporting criteria. This case also exhibited characteristics of efficiency, waste, substitution, and functionality archetypes of BMfS.

The second step in the analysis sought to identify the critical success factors and barriers. A more open coding approach was used to identify these factors, seeking to let key themes within the data to emerge. Any information relating to the answering of the research questions was coded. For a theme to be developed, it had to be mentioned by at least two respondents. The codes were developed iteratively, via a process of abstraction and categorisation, seeking key themes within the data relating to success factors. This allowed those factors facilitating or inhibiting the transition towards BMfS to be identified.

For example, B1, a firm developing a home delivery service for groceries highlighted how they could not achieve their objectives alone, and so had developed several partnerships. These included partnerships with suppliers, but also with charities and other 
Table 6

Overview of businesses included in the sample.

\begin{tabular}{|c|c|c|c|}
\hline Business & Company size/type & Sustainable orientation and achievements & Sustainability Phase \\
\hline 1 & Start-up: Sustainable home food delivery & B-Corp Certification ${ }^{a}$ & Pro-active ex. reporting \\
\hline 2 & $\begin{array}{l}\text { SME: Meat and fish substitute producer using } \\
\text { 'textured' vegetable fibre' }\end{array}$ & Most Innovative SME Netherlands Award & Pro-active ex. reporting \\
\hline 3 & SME: Organic food producer & Strives for fair balance in the supply chain, sourcing only organic produce & Pro-active \\
\hline 4 & Start-up: Sustainable fish wholesaler & Sustainable supply chain management approaches & Pro-active ex. reporting \\
\hline 5 & SME: Fruit juice supplier & Uses HPP technology (cold pasteurisation) to increase shelf life, reducing waste & Pro-active ex. reporting \\
\hline 6 & Start-up: Mushroom producer & Grows mushrooms using coffee waste and without chemical inputs & Pro-active ex. reporting \\
\hline 7 & $\begin{array}{l}\text { Start-up: Delivers organic vegetable boxes to } \\
\text { supermarkets direct from farmers }\end{array}$ & $\begin{array}{l}\text { Ensures fair pricing for suppliers (farmers) and eliminates waste by including all } \\
\text { produce }\end{array}$ & Pro-active ex. reporting \\
\hline 8 & $\underline{\text { SME: }}$ ready meal producer & $\begin{array}{l}\text { No additives or preservatives, and source ingredients locally. Nominated for regional } \\
\text { sustainable entrepreneurship award }\end{array}$ & Pro-active ex. reporting \\
\hline 9 & Start-up: Affordable, organic food supplier & $\begin{array}{l}\text { Work with small organic farmers and employ disadvantaged, socially disrupted } \\
\text { individuals }\end{array}$ & Pro-active ex. reporting \\
\hline 10 & $\begin{array}{l}\text { Start-up: Delivers sustainable lunchboxes to } \\
\text { businesses }\end{array}$ & $\begin{array}{l}\text { Delivers product through a transparent, direct (no middlemen) supply chain, with fair } \\
\text { profit sharing with farmers }\end{array}$ & Pro-active ex. reporting \\
\hline 11 & $\begin{array}{l}\text { Start-up: Food catering sustainability } \\
\text { consultants }\end{array}$ & $\begin{array}{l}\text { Provide advice and tools for caterers and restaurants wanting to be more sustainable. } \\
\text { Activities include stakeholder communication and education. }\end{array}$ & Pro-active ex. reporting \\
\hline 12 & $\begin{array}{l}\text { SME: produces bakery ingredients in several } \\
\text { countries. }\end{array}$ & $\begin{array}{l}\text { Has a socially responsible entrepreneurship working group, integrating sustainability } \\
\text { initiatives into all departments. }\end{array}$ & Pro-active \\
\hline 13 & $\begin{array}{l}\text { Start-up: Water buffalo farm, producing ice- } \\
\text { cream, milk, and meat. }\end{array}$ & Organic meat and milk. Run a 'transparency forum' to share their best practice. & Pro-active ex. reporting \\
\hline 14 & $\begin{array}{l}\text { SME: Ready meal provider to patients within } \\
\text { healthcare organisations. }\end{array}$ & $\begin{array}{l}\text { Focus on local sourcing and responding to specific patient demands, to reduce waste, } \\
\text { using online ordering. }\end{array}$ & Pro-active \\
\hline
\end{tabular}

businesses. These partnerships were initially identified as aiding the development of their business model and so were extracted from the transcript. These extracts were later coded as "collaboration' as they corresponded to similarly themed statements by other participants.

\section{Empirical findings}

\subsection{Key success factors for the transition to business models for sustainability}

The themes that were developed to illustrate the key success factors for the development of BMfS are described below. The description serves to illustrate the character of the category developed, and includes illustrative quotes from the anonymised respondents.

1 Collaboration emerged through the data as a key factor in the successful transition to BMfS. This success factor had two aspects. Firstly, the respondents noted that a BMfS could not exist in isolation:

One problem is that I cannot do this alone (B1).

Businesses require the support of actors both up and downstream in the supply chain to develop a BMfS and act in a sustainability way. For example: suitable suppliers are needed, who are willing to provide sustainable inputs; or, without investors who are willing to examine alternative business approaches, capital and investment would not be available:

We are working for example with Triodos ${ }^{1}$ Bank and some "green" investors and venture capitalists (B2).

Due to the often alternative or novel products produced by BMfS,

\footnotetext{
1 Triodos Bank claims to be a sustainable bank, with the mission to "make money work for positive social, environmental and cultural change” Triodos Bank, 2017. Who we are. Triodos Bank Ziest, The Netherlands.
}

the market had to be prepared or created through education and engagement efforts. This included engaging with customers and consumers to inform and educate them, often through co-creation. These engagement and education efforts were also undertaken with other competing sustainable businesses in order to create a viable market:

For example, we are also working with restaurants and chefs in the area, so that people can try our products as an alternative to meat (B2).

We obviously work with all entrepreneurs really together to collaborate on sustainable and creative solutions (B1).

Co-creation is obviously important because we are going on along the route with the caterer to sustainability (B11).

2 Continuous innovation was an important factor in ensuring that business models become sustainable and then continue to improve. Several respondents noted that a continual drive to improve their sustainability performance, including through innovation, was critical to their success. This drive to improve is likely to have been a key factor in transitioning from a traditional business model, both in terms of a driver and as a factor in pushing a firm to fulfil as many sustainability aspects as possible:

Our continuous drive to stay busy and sustainable has been a key success factor for us (B6).

In that sense, there is an urge for continuous improvement (B3).

3 A clear narrative and vision, conveyed regularly and consistently, was critical for ensuring demand for the products of sustainable business models, and for successful partnerships and for motivating those within the company. This narrative was also noted as needing to be genuine for success. This factor links to a need to create a market and engage with consumers and customers. A clear narrative and vision aided customer engagement efforts, and without customer engagement efforts, a clear and narrative vision would have been harder to convey: 
As much as possible I try vision-sharing both within the company and outside the company ... [it is] especially important to tell our story and thereby create awareness. When you tell your story often enough in the right places the consumer will understand it ... (B9).

Our vision was of course also very important, if we did not have this vision, we would have never started (B7).

4 Profitability emerged as a success factor, as BMfS will not survive, nor thrive, where they do not make money. This was especially the case where the businesses were start-ups, where profitability during initial years can be difficult even for traditional businesses. If a firm is unable to survive in the market place, it is unable to provide the environmental and social values created via the BMfS. In this sense, respondents highlighted how profit (or viability) was needed to realise sustainable outcomes and impacts:

It is also very important that you earn money because otherwise you cannot continue to exist (B2).

The challenge for [our business] related to sustainability is for us to be financially sustainable (B4).

At this time, it is also a matter of survival as a small business (B14).

5 A foundation of sustainability: sustainability was noted as having to be at the heart of everything the business did. As BMfS require the integration of sustainability throughout a business, this success factor came as no surprise. Often respondents noted how sustainability was within the businesses 'DNA', and that it was critical that this fed through to all employees. Sustainability was seen as having to be a core principle and value that percolated into all activities and decisions:

Our enthusiasm with regard to sustainability is important for the employees (B10).

It is important that all our employees have sustainability really in their DNA (B9).

6 Finally, external events were highlighted as critical for some of the businesses. Events beyond the wider environment could impact the potential market for a BMfS. These could include the influence of regulation or consumer trends. But often, serendipitous events were mentioned, such as the 2013 'horse meat' scandal in Europe or the Russian ban on agricultural inputs from certain European countries (including the Netherlands) that started in August 2014:

The meat crisis and the horse meat scandal was obviously very important ... (B5).

The Russian boycott was a major catalyst for us (B10).

\subsection{Barriers to the transition to business models for sustainability}

Whilst a range of factors that enhanced the transition to BMfS were identified, some factors that inhibited this transition were also noted. As with the key success factors, quotes have been taken from that data to illustrate the themes.

1 Lack of support from the wider system. This included a lack of support or facilitating action by the government, which was often seen as a barrier to the transition to BMfS, and at best, a benign influence. The government influence could include distortions to markets that create unsustainable outcomes (such as little taxation on fossil fuels):

The government is not doing much. They stand in the way (B3).

The government has totally played no role for us, not in a positive way but also not negative (B10).

Taxation of energy is not true, it has not made it easy for us to use sustainable energy, for example. So, the government does not help us to become more sustainable (B8).

Wholesalers or supermarkets were also noted as hindering progress, due to their unsustainable practices, and power over prices (and hence profitability). For instance, a firm utilising a BMfS needs access to a supermarket retail environment in order to maximise its reach and impact. Supermarkets acted as gatekeepers to a wide range of consumers. However, access to consumers was often denied, as supermarkets felt there was too little demand for new or novel sustainable food products, or, supermarkets were unwilling to sell products at a price that made them viable:

The retailer does not listen to us but to the consumer, so we try to influence consumers. The retailer is a power block between us and the consumer, and this is really far from desirable, it creates excessive dependence (B9).

Ultimately, it is still the wholesaler or the supermarket itself that determines the price (B2).

2 Principle-agent issues were also highlighted as hindering the transition, for example where businesses were in rented or leased properties, meaning they lacked control over their facilities. In such circumstances, the tenant may want to install proenvironmental equipment, such as a new more efficient boiler or solar panels. However, as a tenant, they may not have the right to make these types of changes. The landlord, although empowered to act, has no incentive as they are not users of the facility. For example:

We also hire the premises so we draw our power from the landlord, we have no choice in what kind of power we have, so I honestly do not know if it is green power or not, we can do nothing about decisions here (B2).

3 External events were again noted, however this time in terms of their ability to have a negative impact. The economic crisis was noted as a specific barrier to the development of BMfS:

We had just begun during the economic crisis, and therefore it was very difficult for us to get capital (B2).

\section{Discussion}

\subsection{Critical success factors: comparisons with previous literature}

The core aim of this research was to identify critical success factors and barriers to the creation of BMfS, based on the case of the Dutch food and beverage industry. From the empirical inquiry, a range of factors were identified, as seen in Tables 7 and 8. The factors that emerged from the open coding were quite different from the initial concepts used to launch the enquiry (see Table 1). An overview of the critical success factors that emerged during the analysis can be seen in Fig. 3.

An overview of the comparison between the results and the 
Table 7

Key success factors for the transition to BMfS.

\begin{tabular}{ll}
\hline Key success factors & Number of participants noting factor \\
\hline Collaboration & 9 \\
Continuous innovation & 7 \\
A clear narrative and vision & 7 \\
Profitability & 6 \\
A foundation of sustainability & 5 \\
External events & 3 \\
\hline
\end{tabular}

Table 8

Barriers to the transition to BMfS.

\begin{tabular}{ll}
\hline Barriers to the transition to BMfS & Number of participants noting factor \\
\hline Lack of support from wider system & 11 \\
Principle-agent issues & 3 \\
External events & 5 \\
\hline
\end{tabular}

organisational change management factors identified through the literature review is presented in Table 9. The right column highlights which change management drivers identified through the literature review link to the empirically derived critical success factors. Some of the empirically derived critical success factors identified through the data analysis do not correspond to any of the change management drivers.

Collaboration has no direct comparison with the organisational change management concepts. It does correspond well to characteristics of BMfS, such as costs and benefits being shared more widely (Boons and Lüdeke-Freund, 2013; Tencati and Zsolnai, 2012), as well as linking to the transformative/proactive phase through co-creation in the supply chain (Van Tulder et al., 2013; Visser, 2014). The characteristics highlighted in the literature are not success factors, but their confirmation as potentially important determinants in the transition to BMfS in the empirical sample could mean that greater emphasis should be placed on these aspects for businesses wishing to transition.

The critical success factor of a clear narrative and vision does link well to the organisational change management factor of (proactive) leadership. This factor was highlighted in the literature as important partly because it encouraged the inclusion of employees (Dawson, 1994; Lozano, 2009b; Lozano et al., 2015). A clear narrative and vision can also be linked to the importance of employee aspiration in driving organisational change (Senge, 1999). Both these factors link well to the internal aspects of narrative and vision (as well as the importance of having a foundation of sustainability), where it was noted that motivating employees, and ensuring their commitment to sustainability, aided the transition to a sustainable business model.

The factor continual innovation has no clear links to the organisational change management literature. However, as this is a potentially broad and generic factor, it could be argued that such a factor is implicit within these concepts. Both the organisational change management and the sustainable business literature deal with change and innovation, and Schaltegger et al. (2011) notes that a continuous business case is required for BMfS.

The need for profitability links well to the role of economic benefits in organisational change (Benn et al., 2014; Cannon, 1994). The more normative orientation of the BMfS literature, however, means the importance of this factor is somewhat overshadowed by the need for more holistic performance (Schaltegger et al., 2011; The Natural Step, 2016; van Hemel and Cramer, 2002). That said, the BMfS literature does note that sustainability is incorporated from environmental, social, and economic elements. Economic performance can be considered to be a precondition for the successful transition to BMfS.

External factors were noted as both facilitators and barriers. Whilst the literature acknowledges that a wide range of factors can

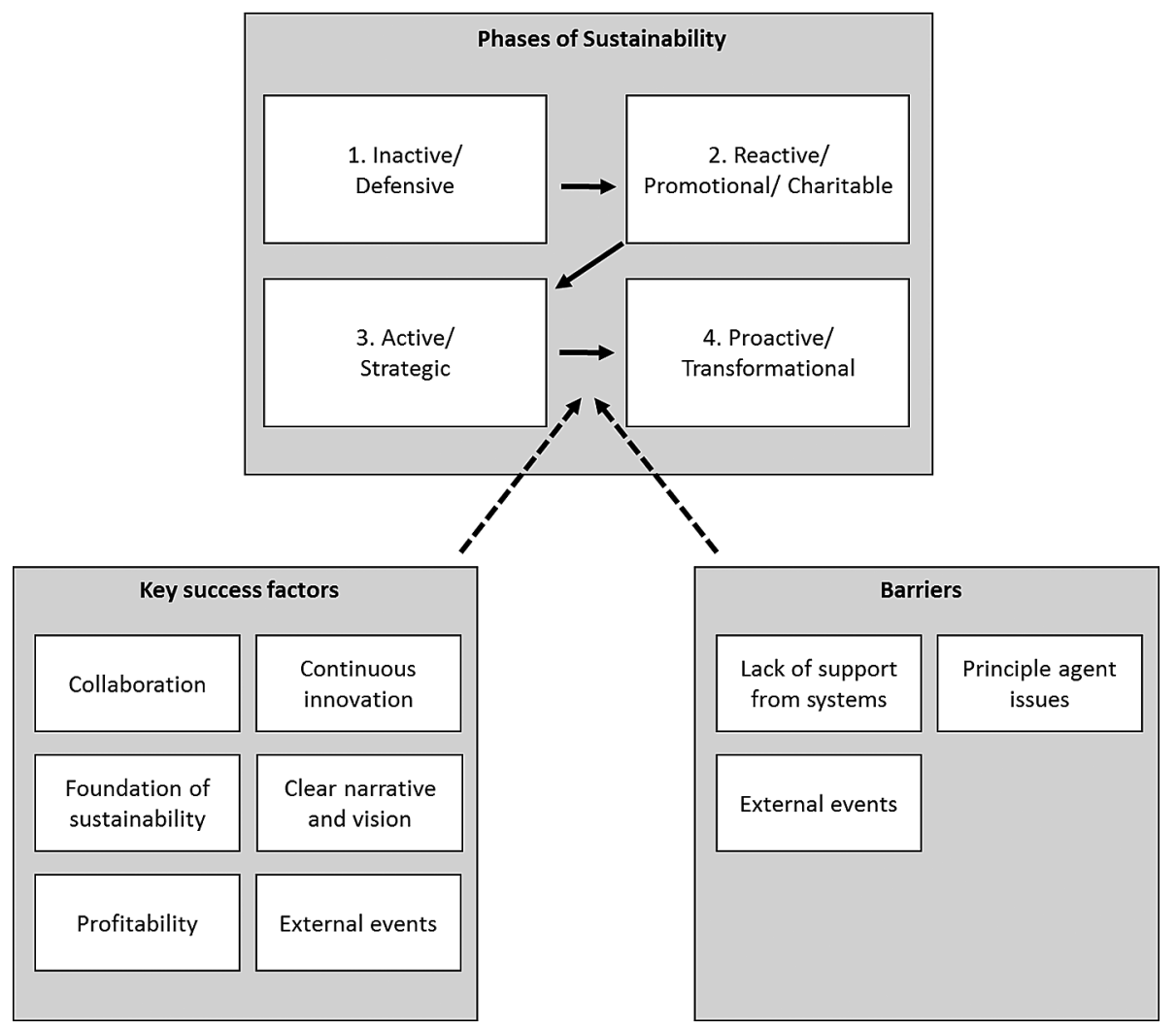

Fig. 3. Key success factors and barriers for the transition to sustainable business models in the Dutch food and beverage industry. 
Table 9

Comparison of results with organisational change management concepts.

\begin{tabular}{ll}
\hline $\begin{array}{l}\text { Critical success factors and barriers developed } \\
\text { from results of data analysis }\end{array}$ & Organisational change management factors identified from literature review \\
\hline Collaboration & - \\
Clear narrative and vision & Proactive leadership (partly confirmed) (Dawson, 1994; Hargreaves and Fink, 2012; Lozano, 2009b) \\
& Aspiration (part confirmed) (Cameron and Green, 2009; Senge, 1999) \\
Continuous innovation & - \\
Foundation of sustainability & Proactive leadership (part confirmed) (Dawson, 1994; Hargreaves and Fink, 2012; Lozano, 2009b) \\
& Aspiration (part confirmed) (Cameron and Green, 2009; Senge, 1999) \\
Profitability & Economic benefits (confirmed) (Benn et al., 2014; Cannon, 1994; \\
& Schaltegger et al., 2011; The Natural Step, 2016) \\
External events & External factors (confirmed) (Dawson, 1994; Ditlev-Simonsen and Midttun, 2011) \\
& Diagnosis (part confirmed) (Cameron and Green, 2009; Carr, 2001) \\
& Visible crises (part confirmed) (Henniker-Major, 2014; Kotter, 1996) \\
Lack of support from system & External factors (confirmed) (Dawson, 1994; Ditlev-Simonsen and Midttun, 2011) \\
Principle-agent issues & - \\
External events & External factors (confirmed) (Dawson, 1994; Ditlev-Simonsen and Midttun, 2011) \\
\hline
\end{tabular}

be included in this category (Dawson, 1994; Ditlev-Simonsen and Midttun, 2011), within the food and beverage industry context, these included chance events, such as the 'horse meat' scandal, the Russian boycott of EU agricultural exports etc. Such serendipity was however taken advantage of. An ability to utilise chance events and see them as business opportunities can also to some extent be seen to confirm a role for diagnosis in the transition to BMfS, as noted within the organisational change management literature. Further, events such as the food safety scare examples noted by the respondents could link to the role of visible crises highlighted as a factor in organisational change management (Kotter, 1996).

The importance of the external environment is emphasised in previous research that highlights the ability of the wider innovation system as well as open innovation approaches to aid BMfS innovation and overcome the barriers it can face (Asswad et al., 2016; Laukkanen and Patala, 2014). Our contribution is to highlight a range of critical success factors that are focused to a greater extent on internal processes.

\subsection{Barriers to the transition to business models for sustainability}

Whilst success factors are identified, the research also highlighted barriers, whose documentation can be of equal value; it should be noted that the lack of some of the critical success factors could in themselves be argued to represent barriers. Specifically, however, the wider system within which BMfS operate was highlighted as troublesome, with both government and retailers highlighted as an example. Principle-agent issues were also noted, which may not be surprising as these are well represented within the wider sustainability literature as a barrier (Baumgartner, 2011). This links to the co-evolution of business models with socio-technical systems changes, and could highlight that the socio-technical systems associated with the food and beverage sector are not supporting business model innovation (Boons et al., 2013; Loorbach and Wijsman, 2013). Indeed, previous research has highlighted the impact of barriers such as regulatory, market and financial, behavioural and social factors, and the role that the innovation system plays in facilitating the development of diffusion of BMfS (Laukkanen and Patala, 2014). Our results complement this previous work by adding a more internally and management focused explanation for the difficulties faced in the development of BMfS.

The results that barriers such as fear or diagnosis were not confirmed or only partly confirmed could in part be explained by the specific empirical context of the research and due to potential biases. For example, respondents are unlikely to have been willing to note fear as a barrier, due to the negative connotations associated with the concept. Further, as sustainability is already high on the agenda within the food and beverage industry, diagnosis of this problem is to some extent already self-evident, reducing the importance of the role of diagnosis in a transition.

Fewer barrier themes emerged from the data than those for critical success factors. This was a result of the coding process and the fact that respondents reported a narrower set of factors acting as barriers than compared to the success factors.

\subsection{Implications for business}

Managers should take the identified success factors into account and incorporate them into their strategic planning when considering making the transition towards sustainable business.

The results show that sustainability should be the point of departure and the foundation of the business model. To successfully transition to a BMfS, an owner or manager needs to establish the key sustainable principles or issues the business model will be based upon (Bocken and Short, 2016). This needs to be clearly articulated, providing clear guidance and leadership to both internal and external stakeholders and potential collaborators.

These principles, however, need to be balanced with the need for the firm to survive within competitive markets (Schaltegger et al., 2016). A business case for the business model needs to be established and executed successfully (Schaltegger et al., 2011). Further, this business case and the business model itself needs to be continuously reassessed, with opportunities for improvement identified and taken.

Owners and managers also need to ensure that they have supportive relationships and supportive ecosystems around their firm. Collaboration is required to successful execute the transition to, or development of a BMfS. This is also an example of how the different success factors are mutually supportive. For instance, collaboration is likely to be enhanced where a clear narrative and vision exists. Managers should also remember not to alter business model aspects in isolation, and to consider the business model as a whole when innovating (Long et al., 2017). The role of partners and other actors in the wider innovation system should also be recognised and leveraged where possible (Asswad et al., 2016; Laukkanen and Patala, 2014).

The role that external factors play, especially as barriers, advocates a role for the government. Greater effort could be taken to ensure supportive regulation, but also increasing awareness of the need for sustainability among retailers, consumers, and suppliers of food and beverage products. The emergence of collaboration as a critical success factor further highlights the importance of these relationships and the ecosystem that surrounds a business transitioning towards a BMfS. 


\section{Conclusions}

This study has explored and identified critical success factors and barriers to the transition towards BMfS, with an empirical focus on 14 SMEs and start-ups in the Dutch food and beverage industry. This was achieved by firstly developing a process for identifying BMfS, using two different but complementary concepts of BMfS. Second, a framework was developed based on the transition towards BMfS and organisational change management literature. We find that collaboration, a clear narrative and vision, continual innovation, a sustainable foundation, profitability, and serendipitous external events emerge as critical success factors for the transition to BMfS. Barriers include external events, principle-agent problems as well as a lack of support from wider actors and systems.

The results highlight that the creation of BMfS is dependent on a range of internal and external factors. Our research has unpacked and highlighted some of the key management factors that act as critical success factors within the context of the Dutch food and beverage sector. Our results compliment previous explorations of the barriers to sustainable business model innovation, which drew on innovation system and open innovation concepts (Asswad et al., 2016; Laukkanen and Patala, 2014).

Similar and overlapping factors were identified across this research and previous studies. For instance, the importance of economic effects or the importance of a supportive government. Where this is the case, such factors take on a new level of validity, as they have been identified using different theoretical and conceptual lenses and across different contexts. While this research focused on the specific context of SMEs and start-ups in the Dutch food and beverage sector, the factors identified are likely to be applicable to other contexts as well. For example, the importance of continual innovation or profitability are likely to act as critical success factors for BMfS in other competitive sectors and contexts. Characteristics such as the proximity of consumers to the BMfS, the structure of the market (the food and beverage market has several large multinational actors as well as many SMEs and start-ups), or the competitiveness of the market, are likely to impact the applicability of the results to other contexts. It is possible that in less competitive contexts, continual innovation and improvement may be less critical, while principle-agent issues may be less pernicious for larger actors transitioning to BMfS. Further research on different sized businesses, within different sectors or geographical contexts will be required to confirm whether the success factors identified in this research are applicable to different contexts. Further research is needed as this research was qualitative and explorative by nature and had a limited number of data points.

\section{Appendix A}

Interview constructs and questions

Interview constructs and questions for sustainable business transition phases.

\begin{tabular}{|c|c|c|c|c|}
\hline & Constructs & Operationalization & Questions & References \\
\hline \multirow{12}{*}{$\begin{array}{r}\text { 4-Phases } \\
\text { Model }\end{array}$} & Vision on & Holistic, strategic & How important is sustainability for your company? & Van Tilburg et al., 2012 \\
\hline & sustainability & & What is the/your definition of sustainability? & Stoughton and Ludema \\
\hline & & & $\begin{array}{l}\text { What is the role of sustainability within your organization? } \\
\text { What is your business purpose of sustainability? }\end{array}$ & $(2012)$ \\
\hline & Orientation external & Cosmopolitan, society & What is your (external) orientation regarding sustainability? & Van Tilburg et al., 2012 \\
\hline & developments & & & \\
\hline & $\begin{array}{l}\text { Business case } \\
\text { elements }\end{array}$ & $\begin{array}{l}\text { Costs, clients, law, reputation, identity, } \\
\text { long-term continuity }\end{array}$ & To what extent is sustainability part of your Business Model? & Van Tilburg et al., 2012 \\
\hline & Transparency & $\begin{array}{l}\text { Full transparency (transparency vs. } \\
\text { competitive advantage) }\end{array}$ & $\begin{array}{l}\text { How sustainable is your company at this moment regarding } \\
\text { sustainability? }\end{array}$ & Van Tilburg et al., 2012 \\
\hline & Reporting & Integrated with intertwined strategy & Can I have a copy of your Sustainability Report? & Van Tilburg et al., 2012 \\
\hline & Stakeholders & Society & $\begin{array}{l}\text { How does your organization see itself regarding sustainability within } \\
\text { the society? }\end{array}$ & Van Tilburg et al., 2012 \\
\hline & $\begin{array}{l}\text { Supply chain } \\
\text { approach }\end{array}$ & Co-creation & $\begin{array}{l}\text { What do you think of the role of the suppliers regarding sustainability } \\
\text { issues? }\end{array}$ & Van Tilburg et al., 2012 \\
\hline & & & $\begin{array}{l}\text { What is the role of the suppliers regarding sustainable } \\
\text { entrepreneurship? }\end{array}$ & \\
\hline & $\begin{array}{l}\text { Dominant functional } \\
\text { discipline }\end{array}$ & Management/Board and strategy & $\begin{array}{l}\text { What is the vision on sustainability for the organization and what are } \\
\text { the long-term plans for sustainability? }\end{array}$ & Van Tilburg et al., 2012 \\
\hline
\end{tabular}

Constructs and interview questions for BMfS archetypes: (all Bocken et al., 2014).

\begin{tabular}{|c|c|c|c|}
\hline & Construct & Operationalization & Questions \\
\hline \multirow[t]{8}{*}{$\begin{array}{l}\text { 8-Archetye } \\
\text { Model }\end{array}$} & Efficiency & $\begin{array}{l}\text { Low-carbon manufacturing costs; lean manufacturing; } \\
\text { dematerialization; }\end{array}$ & $\begin{array}{l}\text { Does your organization focus on maximising material and energy efficiency? If so, } \\
\text { how? }\end{array}$ \\
\hline & Waste & Circular economy; reuse, recycle, remanufacture; & Does your organization focus on creating value from waste? If so, how? \\
\hline & Substitution & Renewable energy sources; biomimicry; green chemistry & $\begin{array}{l}\text { Does your organization focus on the substitution of renewable energy and natural } \\
\text { processes? If so, how? }\end{array}$ \\
\hline & Functionality & Product oriented PSS-maintenance, etc. & $\begin{array}{l}\text { Does your organization focus on delivering functionality rather than ownership? If } \\
\text { so, how? }\end{array}$ \\
\hline & Stewardship & $\begin{array}{l}\text { Biodiversity protection; ethical trade; choice editing by } \\
\text { retailers; etc. }\end{array}$ & Does your organization focus on adopting a stewardship role? If so, how? \\
\hline & Sufficiency & $\begin{array}{l}\text { Consumer education; demand management; product } \\
\text { longevity; }\end{array}$ & Does your organization focus on encouraging sufficiency? If so, how? \\
\hline & Repurpose & $\begin{array}{l}\text { Not for profit; hybrid businesses; localization; base of } \\
\text { pyramid solutions }\end{array}$ & Does your organization focus on repurposing for society? If so, how? \\
\hline & Scale-up & Incubators; open innovation; crowdsourcing/funding; & Does your organization focus on developing scale-up solutions If so, how? \\
\hline
\end{tabular}


Constructs and interview questions for organisational transition management.

\section{Pro-Active leadership Requests that team members make decisions;} Shares a compelling vision; Foresees and influences change; Teaches team to be selfreliant; Focuses on achieving performance outcomes;

$\begin{array}{ll}\begin{array}{l}\text { Organisational } \\ \text { Change Management }\end{array} & \text { Aspiration } \\ & \text { Economic benefits }\end{array}$

Organization produces continuous learning and
growth and has positive vision

The higher the potential for economic benefits, the more important it becomes as change driver.

External driving factors Political and financial upheaval, new technologies, regulatory change, worldwide competition, and consumer preferences

Correct diagnosis Diagnosis of something being wrong in the organization and needing to be changed

Upsurge of visible crises The upsurge of visible crises that can attract attention and push up urgency levels

Non-active leadership

The lack of a pro-active attitude towards sustainability

Fear

Organization produces short-term changes, but negative vision

Economic losses

The failure to obtain economic benefits

diminishes the potential and need for change.
External hindering
factors

Wrong diagnosis

Upsurge of visible crises
Political and financial disruption, new technologies, regulatory change, worldwide competition, and consumer preferences The lack of the ability to diagnose problems within the organization

The upsurge of visible crises that can attract attention and push up urgency levels
Do you, or does your supervisor has a pro-active attitude towards sustainable change, if so, how?

Dawson 1994 sustainability, if so, how?

Do you see sustainability as a business

Cannon 1994 opportunity, if so, how?

What do you think of the role of the government/customers regarding sustainability issues and entrepreneurship?

Is your transition to a SBM due to the diagnosis Carr 2001 of something being wrong within the organization? If so, how? visible crises? If so, how?

Collected through corresponding positive question.

Collected through corresponding positive question.

Did the lack of a business case have an influence on the implementation of SBM? Did the extra costs of transparency have an influence on your SBM?

Did the economic crisis have influence on the implementation of your SBM?

Collected through corresponding positive question.

Collected through corresponding positive question.
Does your organization have a positive vision of Senge 1999

Is your transition to a SBM due to the upsurge of Kotter 1996
Dawson 1994

Dawson 1994

Senge 1999

Cannon 1994

Dawson 1994

Carr 2001

Kotter 1996

\section{References}

Asswad, J., Hake, G., Marx Gómez, J., 2016. Overcoming the barriers of sustainable business model innovations by integrating open innovation. In: Abramowicz, W., Alt, R., Franczyk, B. (Eds.), Business Information Systems: 19th International Conference, BIS 2016, Leipzig, Germany, July, 6-8, 2016, Proceedings. Springer International Publishing, Cham, pp. 302-314.

Baumgartner, R.J., 2011. Critical perspectives of sustainable development research and practice. J. Clean. Prod. 19, 783-786.

Benn, S., Dunphy, D., Griffiths, A., 2014. Organizational Change for Corporate Sustainability, third ed. Routledge, Oxon.

Birkin, F., Cashman, A., Koh, S.C.L., Liu, Z., 2009. New sustainable business models in China. Bus. Strategy Environ. 18, 64-77.

Blok, V., Long, T.B., Gaziulusoy, A.I., Ciliz, N., Lozano, R., Huisingh, D., Csutora, M., Boks, C., 2015. From best practices to bridges for a more sustainable future: advances and challenges in the transition to global sustainable production and consumption: introduction to the ERSCP stream of the Special volume. J. Clean. Prod. 108 (Part A), 19-30.

Bocken, N.M.P., Short, S.W., 2016. Towards a sufficiency-driven business model: experiences and opportunities. Environ. Innovation Soc. Trans. 18, 41-61.

Bocken, N., Short, S., Rana, P., Evans, S., 2013. A value mapping tool for sustainable business modelling. Corp. Gov. Int. J. Bus. Soc. 13, 482-497.

Bocken, N.M.P., Short, S.W., Rana, P., Evans, S., 2014. A literature and practice review to develop sustainable business model archetypes. J. Clean. Prod. 65, 42-56.

Bohnsack, R., Pinkse, J., Kolk, A., 2014. Business models for sustainable technologies: exploring business model evolution in the case of electric vehicles. Res. Policy 43, 284-300.

Boons, F., Lüdeke-Freund, F., 2013. Business models for sustainable innovation: state-of-the-art and steps towards a research agenda. J. Clean. Prod. 45, 9-19.

Boons, F., Montalvo, C., Quist, J., Wagner, M., 2013. Sustainable innovation, business models and economic performance: an overview. J. Clean. Prod. 45, 1-8.

Cameron, E., Green, M., 2009. Making Sense of Change Management: a Complete Guide to the Models, Tools and Techniques of Organizational Change. Kogan Page, London, UK.

Cannon, T., 1994. Corporate Responsibility. A Textbook on Business Ethics, Governance, Environment: Role and Responsibilities. Pitman publishing, London.

Carr, A., 2001. Understanding emotion and emotionality in a process of change. J. Organ. Change Manag. 14, 421-436.

Chesbrough, H., 2010. Business model innovation: opportunities and barriers. Long. Range Plan. 43, 354-363.

Chesbrough, H., Rosenbloom, R.S., 2002. The role of the business model in capturing value from innovation: evidence from Xerox Corporation's technology spin-off companies. Ind. Corp. Change 11, 529-555.

Chun, Y.-Y., Lee, K.-M., 2013. Life cycle-based generic business strategies for sustainable business models. J. Sustain. Dev. 6, 1.

Clinton, L., Whisnant, R., 2014. Model Behavior - 20 Business Model Innovations for Sustainability. SustainAbility, London.

Dawson, P., 1994. Organisational Change. A Processual Approach. Paul Chapman Publishing Ltd., London.

de Medeiros, J.F., Ribeiro, J.L.D., Cortimiglia, M.N., 2014. Success factors for environmentally sustainable product innovation: a systematic literature review. J. Clean. Prod. 65, 76-86.

Delahaye, R., Edens, B., Graveland, C., Hoekstra, R., Koren, W., Lammers, E., Lodder, B., Pieters, A., van Rossum, M., Schenau, S., Schuerhoff, M., Smits, J.P., van Velzen, M., Verberk, M., Vuik, J., Zult, D., 2013. Environmental Accounts of the Netherlands 2012. Statistics Netherlands, Den Haag, Netherlands.

Ditlev-Simonsen, C.D., Midttun, A., 2011. What motivates managers to pursue corporate responsibility? a survey among key stakeholders. Corp. Soc. Responsib. Environ. Manag. 18, 25-38.

Ebben, J.J., Johnson, A.C., 2005. Efficiency, flexibility, or both? Evidence linking strategy to performance in small firms. Strategic Manag. J. 26, 1249-1259.

FoodDrinkEurope, 2012. Environmental Sustainability Vision towards 2030: Achievements, Challenges and Opportunities. FoodDrinkEurope, Brussels, Belgium.

Geissdoerfer, M., Bocken, N.M.P., Hultink, E.J., 2016. Design thinking to enhance the sustainable business modelling process - a workshop based on a value mapping process. J. Clean. Prod. 135, 1218-1232.

Gilgun, J.F., 2011. Coding in Deductive Qualitative Analysis. Amazon Digital Services, USA.

Gilgun, J.F., 2015. Deductive Qualitative Analysis as Middle Ground: Theory-guided Qualitative Research. Amazon Digitial Services LLC.

Hargreaves, A., Fink, D., 2012. Sustainable Leadership. John Wiley \& Sons.

Henniker-Major, 2014. The Bangladesh Factory Collapse: a Case for Intervention and Policy Change. Seven Pillars Institute For Global Finance and Ethics.

Keijzers, G., 2002. The transition to the sustainable enterprise. J. Clean. Prod. 10, 349-359.

Kotter, J.P., 1996. Leading Change. Harvard Business Press.

Lantos, G.P., 2001. The boundaries of strategic corporate social responsibility. J. Consumer Mark. 18, 595-632.

Laukkanen, M., Patala, S., 2014. Analysing barriers to sustainable business model innovations: innovation systems approach. Int. J. Innovation Manag. 18 (6).

Long, T.B., Tallontire, A., Young, W., 2015. CSR, voluntary standards and sustainability. In: Kopnina, H., Shoreman-Ouimet, E. (Eds.), Sustainability - Key Issues. 
Routledge, UK.

Long, T.B., Blok, V., Poldner, K., 2017. Business models for maximising the diffusion of technological innovations for climate-smart agriculture. Int. Food Agribus. Manag. Rev. 20 (1), 5-23.

Loorbach, D., Wijsman, K., 2013. Business transition management: exploring a new role for business in sustainability transitions. J. Clean. Prod. 45, 20-28.

Loorbach, D., van Bakel, J.C., Whiteman, G., Rotmans, J., 2009. Business Strategies for Transitions towards Sustainable Systems. Business Strategy and the Environment.

Lozano, R., 2009a. Orchestrating Organisational Change for Corporate Sustainability: Strategies to Overcome Resistance to Change and to Facilitate Institutionalization. Cardiff University Business School. University of Cardiff, Cardiff.

Lozano, R., 2009b. Orchestrating Organisational Change for Corporate Sustainability: Strategies to Overcome Resistance to Change and to Facilitate Institutionalization. Cardiff University.

Lozano, R., 2013. Are companies planning their organisational changes for corporate Sustainability? An analysis of three case studies on resistance to change and their strategies to overcome it. Corp. Soc. Responsib. Environ. Manag. 20, $275-295$.

Lozano, R., Carpenter, A., Huisingh, D., 2015. A review of 'theories of the firm' and their contributions to corporate sustainability. J. Clean. Prod. 106, 430-442.

Lüdeke-Freund, F., Massa, L., Bocken, N.M.P., Brent, A., Musango, J., 2016. Business Models for Shared Value: Main Report. Network for Business Sustainability South Africa, South Africa.

Michaelis, L., 2003. The role of business sustainable consumption. J. Clean. Prod. 11, 915-921.

Osagie, E.R., Wesselink, R., Blok, V., Lans, T., Mulder, M., 2016. Individual competencies for corporate social responsibility: a literature and practice perspective. J. Bus. Ethics 135, 233-252.

Osterwalder, A., Pigneur, Y., 2009. Business Model Generation. Université de Lausanne, Lausanne.

Osterwalder, A., Pigneur, Y., Tucci, C.L., 2005. Clarifying Business Models: Origins Present, and the Future of the Concept, vol. 16. Communications of the Association for Information Systems.

Raworth, K., 2005. Trading Away Our Rights: Women Working in Global Supply Chains. Oxfam, London.

Reisch, L., Eberle, U., Sylvia, L., 2013. Sustainable food consumption: an overview of contemporary issues and policies. Sustain. Sci. Pract. Policy 9, 7-25.

Rockstrom, J., Steffen, W., Noone, K., Persson, A., Chapin, F.S., Lambin, E.F. Lenton, T.M., Scheffer, M., Folke, C., Schellnhuber, H.J., Nykvist, B., de Wit, C.A., Hughes, T., van der Leeuw, S., Rodhe, H., Sorlin, S., Snyder, P.K., Costanza, R. Svedin, U., Falkenmark, M., Karlberg, L., Corell, R.W., Fabry, V.J., Hansen, J., Walker, B., Liverman, D., Richardson, K., Crutzen, P., Foley, J.A., 2009. A safe operating space for humanity. Nature 461, 472-475.

Roelofsen, M., Blok, V., Wubben, E., 2015. Maintaining the CSR-identity of sustainable entrepreneurial firms: the role of corporate governance in periods of business growth. In: Frederiksen, C.S., Idowu, S.O., Mermod, A.Y., Nielsen, M.E.J. (Eds.), Corporate Social Responsibility and Governance: Practice and Theory. Springer, Dordrecht.

Saunders, M., Lewis, P., Thornhill, A., 2009. Research Methods for Business Students. Pearson Education, Essex, UK.

Schaltegger, S., Lüdeke-Freund, F., Hansen, E.G., 2011. Business Cases for Sustainability and the Role of Business Model Innovation. Developing a Conceptual Framework. Leuphana Universität, Lüneburg.

Schaltegger, S., Lüdeke-Freund, F., Hansen, E.G., 2016. Business models for sustainability: a Co-Evolutionary analysis of sustainable entrepreneurship, innovation, and transformation. Organ. Environ. 29 (3), 264-289.

Schneider, S., Spieth, P., 2013. Business model innovation: towards an integrated future research agenda. Int. J. Innov. Manag. 17, 1340001.

Senge, P.M., 1999. The Fifth Discipline. The Art \& Practice of the Learning Organisation. Random House Business Books, London.

Senge, P., 2000. The Art and Practice of the Learning Organization. Doubleday, New York.

Stoughton, A.M., Ludema, J., 2012. The driving forces of sustainability. J. Organ. Change Manag. 25, 501-517.

Stubbs, W., Cocklin, C., 2008. Conceptualizing a "sustainability business model". Organ. Environ. 21, 103-127.

Tencati, A., Zsolnai, L., 2012. Collaborative enterprise and sustainability: the case of slow food. J. Bus. Ethics 110, 345-354.

Triodos Bank, 2017. Who We Are. Triodos Bank Ziest, The Netherlands.

The Natural Step, 2016. Accelerating Change the Natural Step Stockholm, Sweden.

van Hemel, C., Cramer, J., 2002. Barriers and stimuli for ecodesign in SMEs. J. Clean. Prod. 10, 439-453.

Van Tilburg, R., Van Tulder, R., Francken, M., 2012. Duurzaam Ondernemen Waarmaken - Het Bedrijfskundig Perspectief. Koninklijke van Gorcum.

Van Tulder, R., Van Tilburg, R., Francken, M., da Rosa, A., 2013. Managing the Transition to a Sustainable Enterprise: Lessons from Frontrunner Companies. Routledge, London.

Visser, W., 2014. CSR 2.0: Transforming Corporate Sustainability and Responsibility. Springer, London.

Wesselink, R., Blok, V., van Leur, S., Lans, T., Dentoni, D., 1 November 2015. Individual competencies for managers engaged in corporate sustainable management practices. J. Clean. Prod. 106, 497-506.

Young, W., Tilley, F., 2006. Can businesses move beyond efficiency? The shift toward effectiveness and equity in the corporate sustainability debate. Bus. Strategy Environ. 15, 402-415. 